\title{
Mapping Cadmium distribution in roots of Salicaceae through scanning electron microscopy with $\mathrm{x}$-ray microanalysis
}

\author{
Cocozza $C^{(1)}$, Maiuro $L^{(2)}$, Tognetti $\mathbf{R}^{(1)}$
}

\begin{abstract}
A screening in hydroponics was carried out to assess the potential of Cd uptake and metal accumulation in roots of 4 poplar and 2 willow clones. Rooted cuttings were exposed for 3 weeks to $50 \mu \mathrm{M}$ Cd sulphate in a growth chamber. Salicaceae clones were discriminated in their potential to absorb and distribute $\mathrm{Cd}$ in root tissues considering the interaction between metal and macronutrients. SEM-EDXMA was useful to investigate structural modifications and to identify in situ concentration and distribution of elements in roots, establishing indirect correlations between accumulation and localization of the metal. Overall, observations suggested differential patterns between species and clones in accumulating $\mathrm{Cd}$ within the root profile. In conclusion, $\mathrm{Cd}$ accumulation in root levels would hardly be a useful indicator of the ability of plants to translocate metal, independently from other parameters, while Cd location in the root cross-section levels could suggest clone-specific control mechanism to mineral uptake.
\end{abstract}

Keywords: Cadmium, EDXMA-SEM, Salicaceae clones, Phytoremediation, Roots

\section{Introduction}

Heavy metals currently and hazardously affect human, physical and biological components, inducing environmental pollution mainly caused by industrial activities. Among heavy metals, $\mathrm{Cd}$ is of particular concern due to its widespread occurrence and its high toxicity. Cd pollution is increasing in the environment due to mining, industrial usage and anthropogenic activity (Merrington \& Alloway 1994, Zhou 2003) Salt et al. (1998) observed the ability of plants to translocate significant quantities of $\mathrm{Cd}$ to aerial parts, which promoted the idea

(1) Dipartimento di Scienze e Tecnologie per l'Ambiente e il Territorio (STAT),

Università del Molise, c.da Fonte Lappone, I86090 Pesche (Italy); (2) Dipartimento di Scienze e Tecnologie Agro-Alimentari Ambientali e Microbiologiche, Università del Molise, v. De Sanctis, I-86100 Campobasso (Italy)

(a) Claudia Cocozza

(claudia.cocozza@unimol.it)

Received: Oct 05, 2010 - Accepted: Mar 01, 2011

Citation: Cocozza C, Maiuro L, Tognetti R, 2011. Mapping Cadmium distribution in roots of Salicaceae through scanning electron microscopy with $x$-ray microanalysis. iForest 4: 113-120 [online 2011-06-01] URL: http://www.sisef.it/iforest/show.php? id $=563$ to use plants to clean up polluted soils, a process called phytoremediation.

Poplars and willows have the potential to provide a cheap method of cleaning up Cdcontaminated soils because of their high biomass production and high Cd bioaccumulation coefficient (e.g., Dickinson 2000, Robinson et al. 2000). Plant biomass, metal tolerance, and metal accumulation in roots and leaves vary greatly between clones (Dos Santos Utmazian et al. 2007). Phytoextraction potential of a clone is primarily determined by metal concentration and by biomass production (Laureysens et al. 2005). The variability of $\mathrm{Cd}$ distribution among leaves, stem, and roots provides candidate Salicaceae for specific phytoremediation processes of contaminated waters and soils (Pietrini et al. 2010). Considering the impact of Cd on Salicaceae rooting, Lunácková et al. (2003) observed seriously damaged root parts, apex, rhizodermis and cortex, while the structure of central cylinder remained unchanged following treatment, showing resistance of root apical meristem and accumulation of darkly stained material around the central cylinder.

Cadmium comes into plants through the root system. Several transporters have been identified as playing a potential role in the uptake, including the ZIP family (ZRT1/ IRT1-like proteins - Connolly et al. 2002), Ca channels (Perfus-Barbeoch et al. 2002) or members of the Nramp family (Maser et al. 2001), which are normally responsible for the uptake of $\mathrm{Zn}^{2+}, \mathrm{Fe}^{2+}, \mathrm{Ca}^{2+}$ or $\mathrm{Mn}^{2+}$. Once transported across the plasma membrane inside the roots, heavy metal ions may be translocated, in some cases, to the aerial part of the plant via the xylem. Besides, compared to other metals (i.e., As), Cd has high trend to accumulate also in other organs than the roots, like stems and leaves (Clemens 2006, Zacchini et al. 2009). However, roots are interested by stress adjustments earlier than leaves (Kieffer et al. 2009a). Stress exposure in roots occurs immediately upon the beginning of the treatment, when the $\mathrm{Cd}$ content in roots is very high (Kieffer et al. 2009b). Cadmium ions cross plasmalemma and internal membranes through transporters /channels with a low specificity (Clemens 2006). However, the mechanism, accounting for the transport of heavy metals across membranes in plants and its regulation, is far from understood.

Scanning electron microscopy allows for the observation of samples, at high magnifications and good field depth with a minimum preparation, and with the possibility to combine structural and analytical information by energy-dispersive x-ray microanalysis and digital images (SEM-EDXMA). Although SEM-EDXMA has been used with some success to plot the subcellular distribution of metals (e.g., Frey et al. 1997, 2000), a poor sensitivity and interference with other cations (e.g., $\mathrm{K}$ ) may limit $\mathrm{Cd}$ detection. Nevertheless, metal distribution within plant organs and tissues may be a good indicator of detoxification and tolerance mechanisms. In this sense, hydroponic screenings show several advantages (Dos Santos Utmazian et al. 2007) in selecting from a considerable number of individuals while reducing the variability due to the environmental factors (Pulford \& Watson 2003).

The knowledge of Cd effects on the absorption, accumulation and distribution of essential elements, such as $\mathrm{Ca}, \mathrm{Fe}$ and $\mathrm{P}$, in roots is still marginal and remains to be investigated. In the case of the addition of $\mathrm{Ca}$ in a culture medium polluted by $\mathrm{Cd}$, an increase of biomass production in tomato plants was observed by Boulila Zoghlami et al. (2006). Cocozza et al. (2008) showed increasing $\mathrm{Fe}$ and decreasing $\mathrm{P}$ concentrations in root tissues of poplar clones subjected to excess Cd. Cadmium may inhibit Fe translocation from roots to shoots, inducing the inhibition of enzyme Fe(III)-chelate reductase (Alcántara et al. 1994), and consequently $\mathrm{Fe}$ accumulation in roots (Fodor et al. 2005).

In a companion study, Zacchini et al. (2009) defined Cd tolerance, accumulation and translocation ability, in poplar and willow clones treated with $\mathrm{Cd}$ in hydroponic systems. The present study aimed at identifying the distribution of Cd and essential elements in root tissues of six candidate clones of Salicaceae, with screening purposes. We 

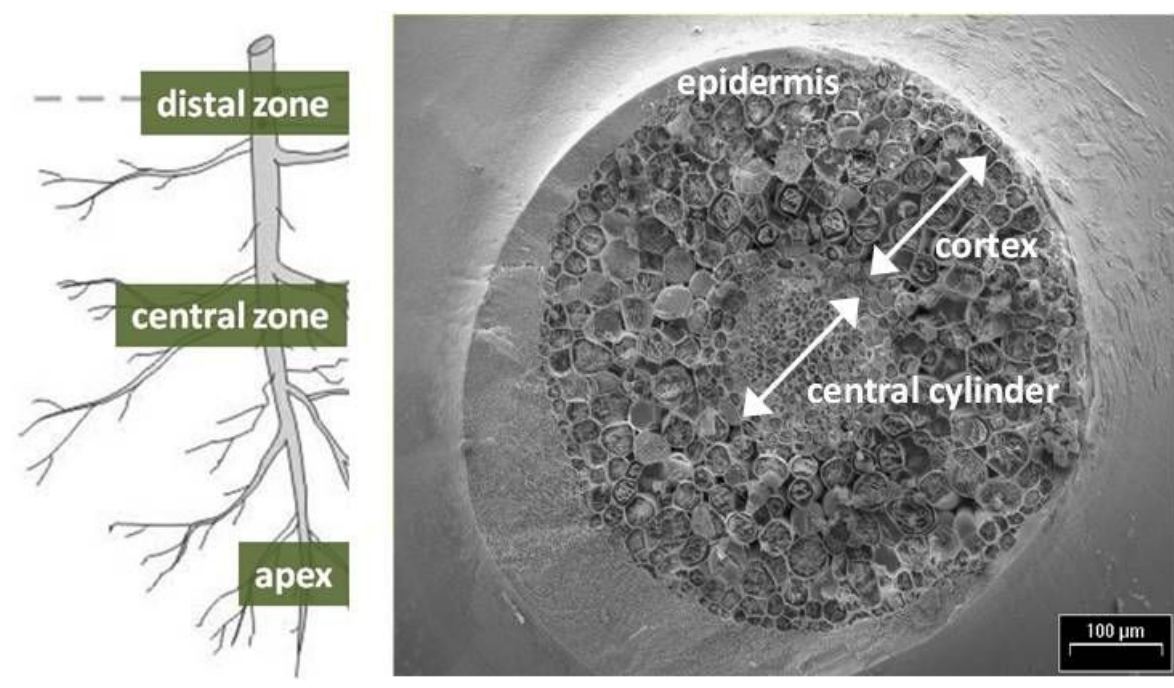

Fig. 1 - Schedule of selection of portions in root levels and root cross-sections.

focused on the investigation of the $\mathrm{Cd}$ allocation strategies, observing the metal distribution at the root level and root cross-section level, and describing symptoms of $\mathrm{Cd}$ toxicity or interference, considering the interaction with others chemical elements. The specific objectives of the study were to: (i) validate whether short-term $\mathrm{Cd}$ treatment induced differential $\mathrm{Cd}$ absorption in the selected clones; (ii) investigate the $\mathrm{Cd}$ allocation in root levels (apex, central and distal zone) and across cross-sections (central cylinder, cortex and epidermis); (iii) to establish a link between the distribution of $\mathrm{Cd}$ and that of essential elements in roots.

\section{Materials and methods}

\section{Plant material and growth conditions}

Woody cuttings of Salicaceae clones (A4A and I-214 Populus $x$ canadensis Mönch.; Poli and 58-861 Populus nigra L.; SS5 Salix $a l b a$ and Cretone Salix sp.) with uniform size $(20 \mathrm{~cm}$ in length and diameter larger than $1 \mathrm{~cm}$ ) were collected from mother plants at IBAF-CNR (Montelibretti - Roma, Italy). Cuttings were grown in pots suitable for hydroponic culture (diameter $13-15 \mathrm{~mm}$ ) with $3 \mathrm{~L}$ of third-strength Hoagland's nutrient solution, $\mathrm{pH}$ 6.5 (Arnon \& Hoagland 1940). The growth conditions were highly controlled with metal halide lamps (Powerstar HQI-TS - Osram, Munich, Germany) providing a photon flux density of $300 \mu \mathrm{mol}$ $\mathrm{m}^{-2} \mathrm{~s}^{-1}$ for $14 \mathrm{~h}$ at $25{ }^{\circ} \mathrm{C}$. During the $10 \mathrm{~h}$ relative humidity was $60-70 \%$. Experimental details can be found in Zacchini et al. (2009) and Pietrini et al. (2010).

After 3 weeks of development, five homogeneous plants per clone were selected and randomly assigned to two groups of treatment: control $(0 \mu \mathrm{M})$ and Cd-treatment (50 $\mu \mathrm{M} \mathrm{CdSO}_{4}$ - Sigma, St. Louis, USA) for three weeks. Each treatment group consisted of five cuttings from each clone. The nutrient solutions were replaced entirely twice a week to prevent depletion of metals and nutrients and to expose plants to a constant metal concentration. An aeration system dark period the temperature was $20^{\circ} \mathrm{C}$. The
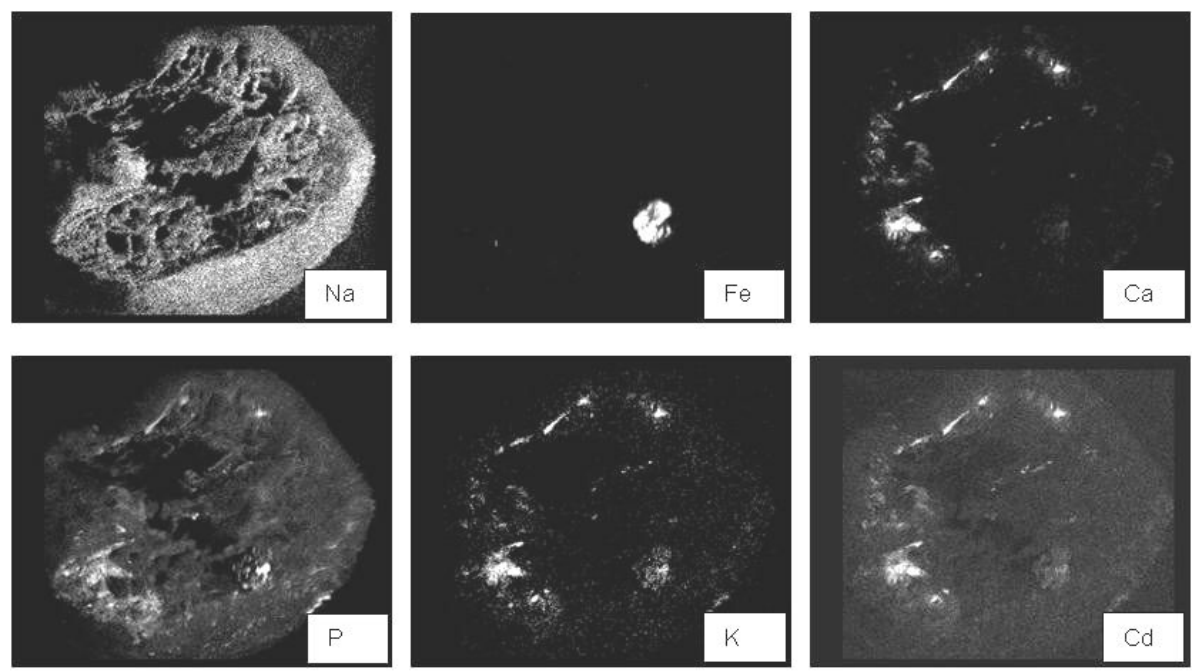

based on pumps was used to avoid lack of oxygen.

\section{Root sampling}

The length of the main root was measured using caliper after three weeks of Cd-treatment, when plants were gently removed from hydroponics.

Three segments of primary roots were taken from each plant and immediately plunged in a solution of 3\% glutaraldehyde (0.01 mol $^{-1}$ phosphate buffer) for microscopic analysis. These segments were approximately $0.5 \mathrm{~cm}$ long: the root apex, the central zone corresponded to the middle of primary root, and the distal zone at the end of primary root.

Energy-dispersive $x$-ray microanalysis (EDXMA) and scanning electron microscope (SEM)

Chemical elements were determined in roots of control and treated plants using scanning electron microscopes (SEM) equipped with energy-dispersive x-ray detector (EDX), which produces point-specific measurements. Root samples were fixed in $3 \%$ glutaraldehyde solution $\left(\mathrm{C}_{5} \mathrm{H}_{8} \mathrm{O}_{2}, 0.01\right.$ mol $\mathrm{l}^{-1}$ phosphate buffer) to maintain protein structures, and then post-fixed for $3 \mathrm{~h}$ in $1 \%$ osmium tetroxide $\left(\mathrm{OsO}_{4}\right)$ to fix proteins and lipids and to improve the contrast of electron microscope pictures. Specimens were subsequently rinsed in fresh buffer and dehydrated through a series of ascending ethanolwater solutions (20-30-40-60-80-95-100\%), with a last wash in acetone for a better $\mathrm{CO}_{2}$ substitution during the dehydration procedure at a pressure of 1200 bars. Afterward, root samples were dried to critical-point (critical point drier K850 - Emitech, Ashford, UK) to produce an electrically conductive surface and thus prevent charging under the electron beam, and then covered with carbon (EDXMA) and gold (SEM) through sputtering (sputter coater K550 - Emitech, Ashford, UK) under vacuum. Carbon was

Fig. 2 - Mapping of specific elements in 58861 roots through $S E M-E D X M A$ analysis. 


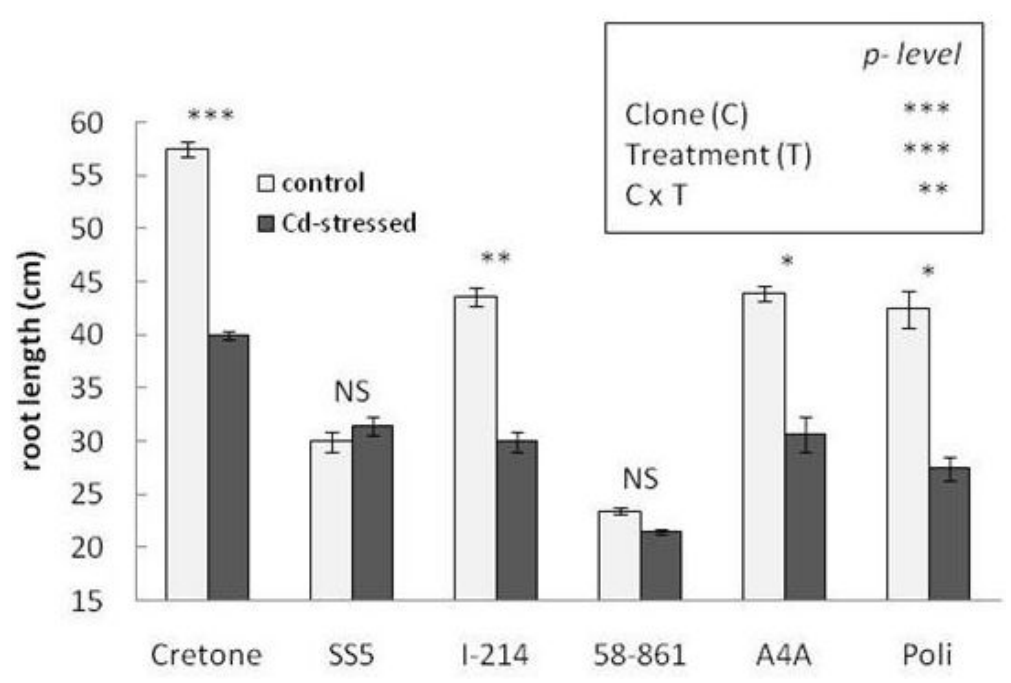

Fig. 3 - Root length measured at the end of Cd exposure, in treated and control plants, for each clone. Data are means $\pm \operatorname{SE}(n=5)$. Asterisks on the histograms indicate significant differences between treatments for each clone (ANOVA test). The analysis of variance for clone and treatment effects is reported in the box. $(*)$ : $\mathrm{P}<0.05 ;(* *)$ : $\mathrm{P}<0.01 ;(* * *)$ : $\mathrm{P}<$ 0.001 ; (NS): not significant.

used instead of metal coating to avoid interference with measured elements, while gold was used to improve conductivity and increase topographic contrast. Observations were done in a SEM (Zeiss DSM 940A, Oberkochen, Germany) operating at $10 \mathrm{kV}$.

\section{Micrographs of roots}

Micrographs were developed for different root levels: the apex, the central and the distal zones. For each root portion, EDXMA was conducted per specific dot considering positions across sections: the central cylinder, the cortex and the epidermis (Fig. 1). Mapping of elements in cross-sections was also produced through EDXMA, as shown in detail in Fig. 2.

\section{Statistical analysis}

The experiment was set up in a completely randomized design with five replicate plants for each treatment $(n=5)$. Data were averaged on a plant basis and subjected to analysis of variance (ANOVA) to test significant differences between the main effect of genotype, treatment and interaction terms. The Student's $t$-test (pairwise) was used to compare $\mathrm{Cd}$ concentration means for these clones. Significant effects were considered at $\mathrm{P} \leq 0.05$.

\section{Results}

\section{Root length}

Cretone, I-214, A4A and Poli showed a decrease in root length upon $\mathrm{Cd}$ exposure comparing to control plants (Fig. 3), and a significant interaction clone $\mathrm{x}$ treatment was found (Fig. 3). Instead, 58-861 and SS5 grew under $\mathrm{Cd}$ treatment with no significant reduction in root length.

\section{Cadmium and macronutrient distribu- tion in roots}

Cadmium and macronutrient contents in roots of selected clones were calculated as percentage amount on a dry weight basis of analyzed sections and are reported in Tab. 1, Fig. 4 and Fig. 5. Macronutrients were not detected in all analyzed points, because of detection limits. Cadmium content in control plants was generally below or near the detection limit and is not shown in Tab. 1.

Cadmium contents were significantly different between root levels in each clone, except for Cretone, and overall higher in 58861, I-214 and A4A (Tab. 1). Clone 58-861 showed relatively high $\mathrm{Cd}$ content in the central zone, A4A and Poli in the apex, and

Tab. 1 - Cadmium contents determined by SEM-EDXMA in control and treated roots of poplar and willow clones at root levels and cross-sections (in \% weight, mean $\pm \mathrm{SE}$ ). One-way ANOVA was performed for $\mathrm{Cd}$ in root levels and cross-sections. $\left({ }^{*}\right): P<0.05$; $(* *): P<$ 0.01 ; (***): $P<0.001$; (NS): not significant.

\begin{tabular}{llcccccc}
\hline \multicolumn{1}{c}{ Level } & Zone & Cretone & SS5 & I-214 & $\mathbf{5 8 - 8 6 1}$ & A4A & Poli \\
\hline Root & apex & 0.425 & 0.943 & 3.435 & 1.518 & 2.878 & 1.458 \\
& & $(0.2)$ & $(0.6)$ & $(0.2)$ & $(0.7)$ & $(0.6)$ & $(0.1)$ \\
& central zone & 2.262 & 1.480 & 2.789 & 4.623 & 1.215 & 0.757 \\
& & $(1.9)$ & $(0.1)$ & $(1.3)$ & $(1.3)$ & $(0.3)$ & $(0.3)$ \\
& distal zone & 1.666 & 2.519 & 2.501 & 2.833 & 1.708 & 0.796 \\
& & $(0.1)$ & $(0.6)$ & $(0.4)$ & $(0.8)$ & $(0.5)$ & $(0.4=$ \\
& p-level & NS & $* * *$ & $*$ & $* * *$ & $* * *$ & $* *$ \\
\hline Root & central cylinder & 0.623 & 1.673 & 2.475 & 1.339 & 1.644 & 0.725 \\
cross-section & & $(0.5)$ & $(0.5)$ & $(0.6)$ & $(0.5)$ & $(0.5)$ & $(0.3)$ \\
& cortex & 1.160 & 1.703 & 2.728 & 4.289 & 2.417 & 1.166 \\
& & $(0.4)$ & $(0.2)$ & $(0.6)$ & $(2.2)$ & $(1.0)$ & $(0.4)$ \\
& \multirow{2}{*}{ epidermis } & 2.570 & 1.809 & 3.522 & 3.545 & 1.740 & 1.120 \\
& & $(1.8)$ & $(1.1)$ & $(1.1)$ & $(0.8)$ & $(0.5)$ & $(0.3)$ \\
& & $*$ & $\mathrm{NS}$ & $* * *$ & $*$ & $* * *$ & $*$ \\
\hline
\end{tabular}

SS5 in the distal zone (Tab. 1). Furthermore, Cd distribution was significantly variable between cross-sections, except for SS5 (Tab. 1). Relatively high $\mathrm{Cd}$ contents were measured in the cortex of 58-861, A4A and Poli, in the epidermis of I-214 and Cretone (Tab. 1).

Total contents of $\mathrm{Cd}, \mathrm{Ca}$ and $\mathrm{P}$ in the root system were significantly different between clones (Tab. 2). Interactions "clone" $\mathrm{x}$ "root level" for Ca and "clone" $\mathrm{x}$ "root cross-section" for $\mathrm{P}$ were not significant (Tab. 2).

In 58-861 (Fig. 4), Fe contents in central and distal zones were higher for treated roots $(\mathrm{P}<0.05)$. In Poli, Fe contents were higher in root apexes and lower in the distal zone of treated roots $(\mathrm{P}<0.001)$. In Cretone, $\mathrm{Fe}$ contents were higher in the central zone of treated roots $(\mathrm{P}<0.05)$, while in the distal zone $\mathrm{Fe}$ was below the detection limit. In Poli, Ca showed lower contents in the central and the distal zone of treated roots $(\mathrm{P}<$ $0.05)$. In A4A, $P$ contents were higher in the central zone of treated roots $(\mathrm{P}<0.001)$. In Poli, $\mathrm{P}$ contents were lower in root levels of treated plants $(\mathrm{P}<0.05)$. In Cretone, $\mathrm{P}$ was detected only in the distal zone of treated roots $(\mathrm{P}<0.05)$

In 58-861 (Fig. 5), significant differences in $\mathrm{Fe}$ and $\mathrm{Ca}$ contents were found through cross sections, being higher in epidermis and cortex of treated roots $(\mathrm{P}<0.01)$. In I-214, $\mathrm{Ca}$ varied significantly between cross sections $(\mathrm{P}<0.05)$, resulting lower in treated roots. Instead, $\mathrm{P}$ contents did not vary through cross sections of roots.

Relationships between elements were analyzed, being significant for each clone only in the case of Cd-Ca contents (Fig. 6). The relationships showed higher slopes in willow than poplar clones, with willows showing higher $\mathrm{Cd}$ contents at similar $\mathrm{Ca}$ contents than poplars. The relationships were highly variable between poplars, evidencing two opposite cases, 58-861 with high $\mathrm{Cd}$ and $\mathrm{Ca}$ 
Fig. 4 - $\mathrm{Fe}, \mathrm{Ca}$ and $\mathrm{P}$ determined by SEM-EDXMA in root levels (apex, central and distal zone), in control and treated roots of poplar and willow clones. Data are expressed in $\%$ weight mean $\pm \mathrm{SE}$
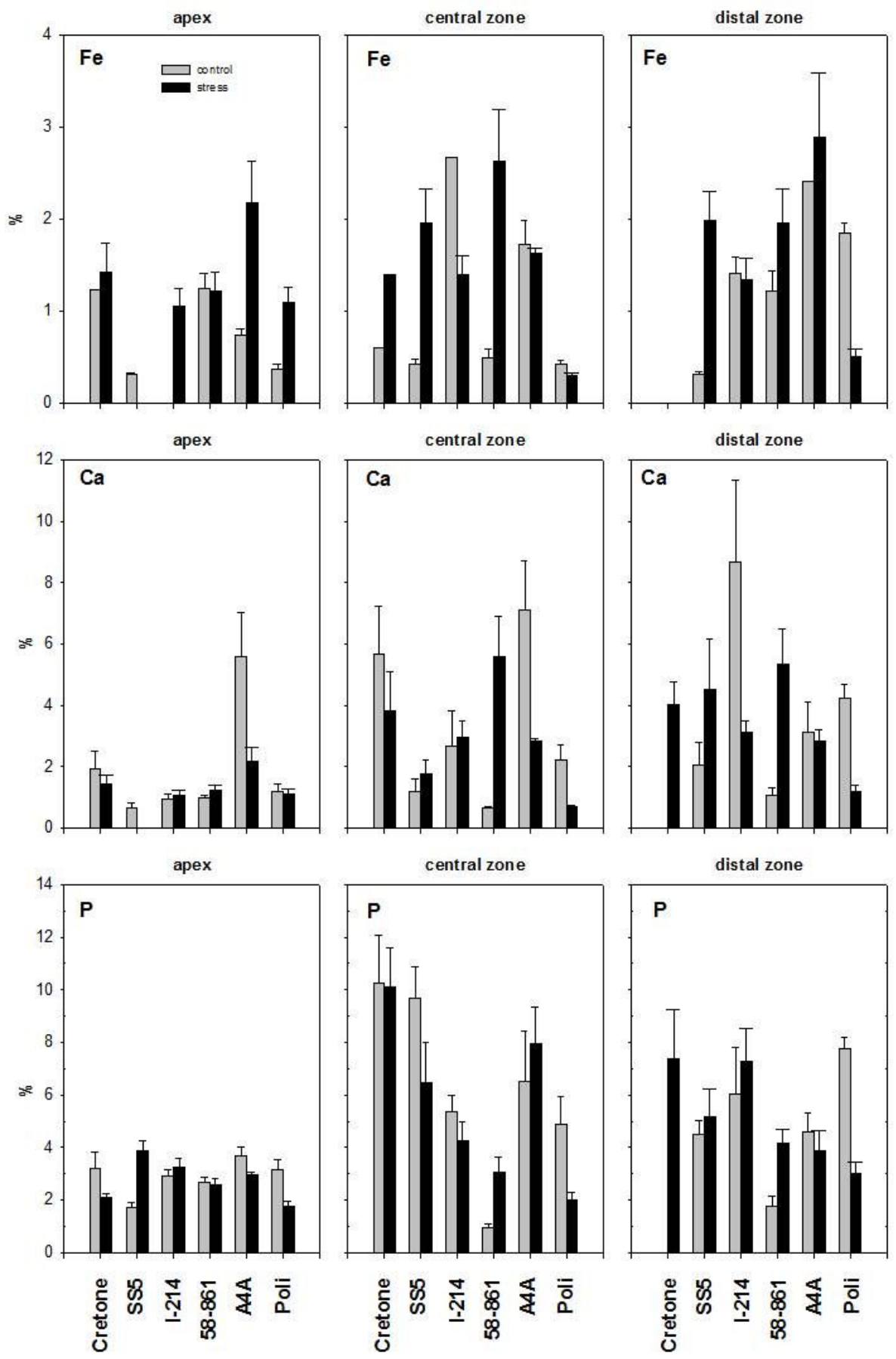

contents, and Poli, characterized by low contents.

\section{Discussion}

The present paper was part of a project aimed at screening poplar and willow clones with tolerance to excess $\mathrm{Cd}$ and uptake capacity for remediation of heavy metal polluted soil. The selection of high performing clones was based on metal accumulation. Overall, all the selected clones analyzed in the present experiment showed a considerable potential for $\mathrm{Cd}$ uptake in roots. This ability is in agreement with previous results obtained in companion studies (Zacchini et al. 2009, Pietrini et al. 2010).

Root length was unaffected by excess $\mathrm{Cd}$ in 58-861 and SS5. Root length defines the capability to absorb water and nutrients, and consequently metal uptake is more strongly related to root length than root weight (Boot \& Mensink 1990, Wei \& Zhou 2006). Root elongation could offer a simple screening parameter for highlighting different sensiti- vity to $\mathrm{Cd}$ in clones of poplar and willow (Zacchini et al. 2009). A fine, widely branched root system was considered a good selection criterion for plant species in phytoremediation (Merkl et al. 2005).

Microanalysis allowed describing some $\mathrm{Cd}$ allocation mechanisms in roots of these Salicaceae, which may support different strategies for tolerating metal, depending on exclusion and detoxification mechanisms. The short-term metal exposure was sufficient for $\mathrm{Cd}$ detection and illustrated a clone-spe- 

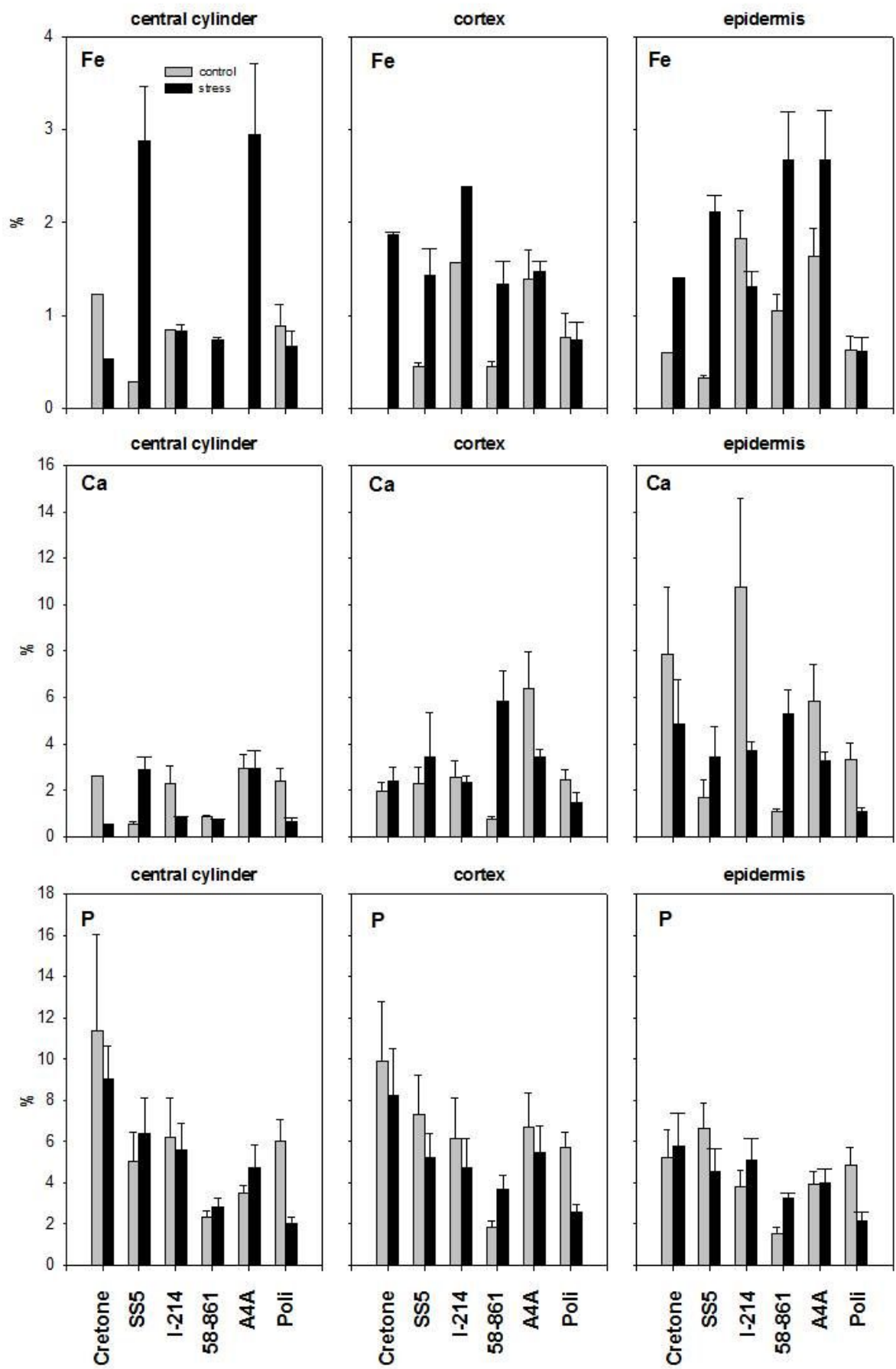

Fig. 5 - $\mathrm{Fe}, \mathrm{Ca}$ and $\mathrm{P}$ determined by SEM-EDXMA in root cross-sections (central cylinder, cortex and epidermis), in control and treated roots of poplar and willow clones. Data are expressed in \% weight mean $\pm \mathrm{SE}$. cific distribution of elements in roots tissues. Total Cd content showed higher ability of poplar clones to remove metal from the solution than willow clones (see also Zacchini et al. 2009), which could imply a substantial capability for more advantageous translocation of metal to the aboveground plant structures. The integrity of root system involved in Cd uptake, coupled with the capacity of translocation to shoots, represents an important factor in screening clones for phytoremediation (Lasat et al. 1997, Shen et al. 1997, Lasat et al. 1998).
A remarkable Cd accumulation was identified in root levels, showing clone-specific $\mathrm{Cd}$ thresholds. A great $\mathrm{Cd}$ accumulation in roots was found in 58-861 and I-214, while this was not the case in Poli, Cretone and SS5. At first glance, 58-861 with unaltered root length under excess $\mathrm{Cd}$ could represent a good candidate for phytoremediation. On the opposite side, SS5 showed high Cd content in the distal zone of its roots, which may suggest a low transport efficiency of $\mathrm{Cd}$, but also an efficient transport mechanism along root and a rapid metal translocation to leaves. Again, higher $\mathrm{Cd}$ contents in root apex than distal zone were observed in A4A and Poli, suggesting a slow metal translocation. Whereas, an intermediate solution for metal transportation could be identified in 58-861, showing high $\mathrm{Cd}$ content in the central zone. Furthermore, Pietrini et al. (2010) observed a decreased transpiration in Cd-treated plants that implies an effect of $\mathrm{Cd}$ on plant water relations. Hence, results on Cd allocation at root level could not be conveniently used in understanding the efficiency or the rapidity of metal transportation 
Tab. 2 - Two-way ANOVA was performed for $\mathrm{Cd}, \mathrm{Fe}, \mathrm{Ca}$ and $\mathrm{P}$ (root levels: apex, central and distal zone; cross-sections: central cylinder, cortex and epidermis). $\left(^{*}\right): P<0.05 ;(* *): P$ $<0.01 ;(* * *): P<0.001$; (NS): not significant.

\begin{tabular}{cccccc}
\hline Elements & $\begin{array}{c}\text { Clone } \\
\text { (C) }\end{array}$ & $\begin{array}{c}\text { Root Level } \\
\text { (RL) }\end{array}$ & $\begin{array}{c}\text { Root } \\
\text { Cross-Section } \\
\text { (RCS) }\end{array}$ & C x RL & C x RCS \\
\hline $\mathrm{Cd}$ & $* *$ & $\mathrm{NS}$ & $*$ & $*$ & $\mathrm{NS}$ \\
$\mathrm{Fe}$ & $\mathrm{NS}$ & $\mathrm{NS}$ & $* *$ & $*$ & $* *$ \\
$\mathrm{Ca}$ & $*$ & $* *$ & $* * *$ & $\mathrm{NS}$ & $*$ \\
$\mathrm{P}$ & $* * *$ & $* * *$ & $\mathrm{NS}$ & $* * *$ & $\mathrm{NS}$ \\
\hline
\end{tabular}
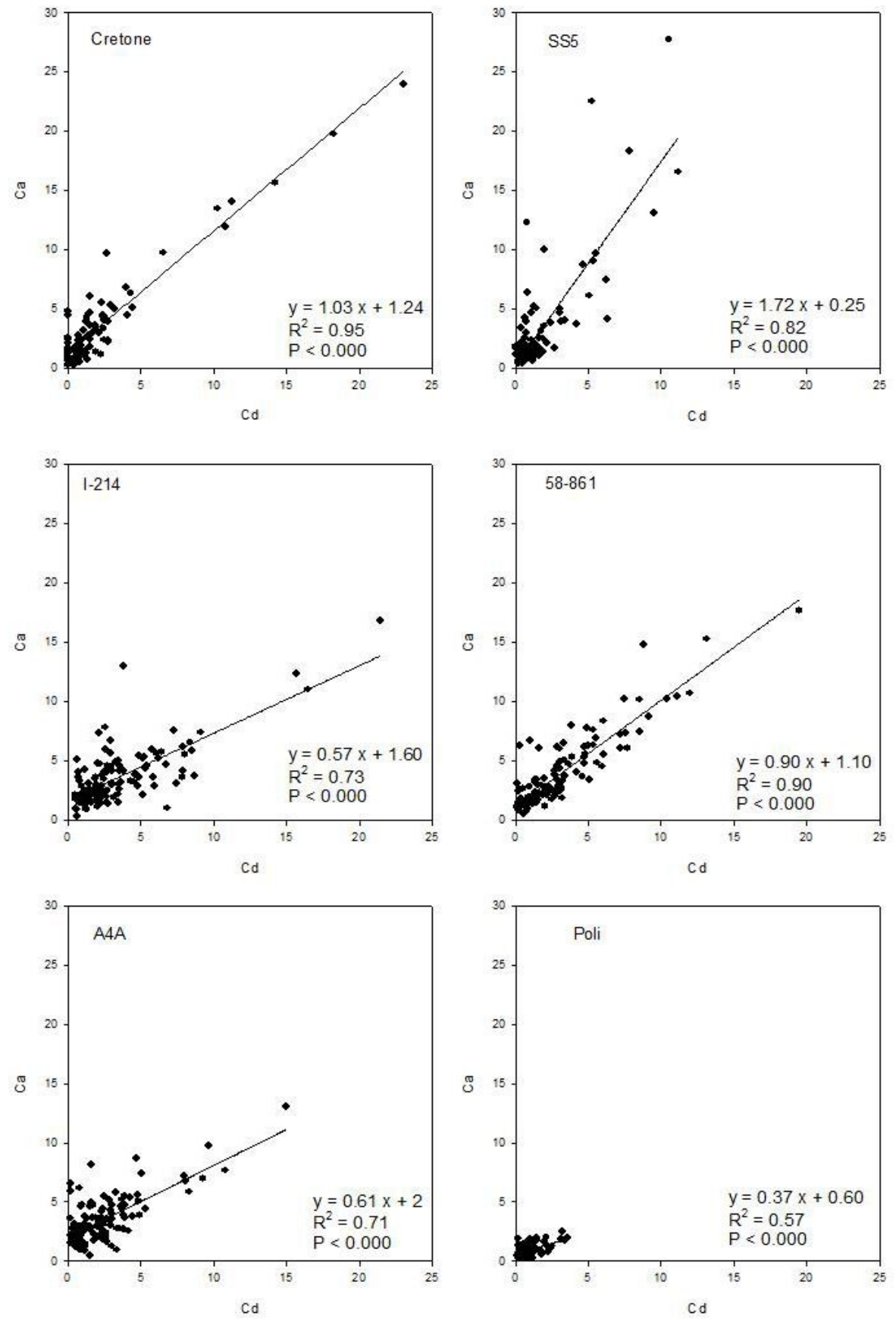

Fig. 6 - Relationships between $\mathrm{Cd}$ and $\mathrm{Ca}$ contents (in \% weight) in each clone.

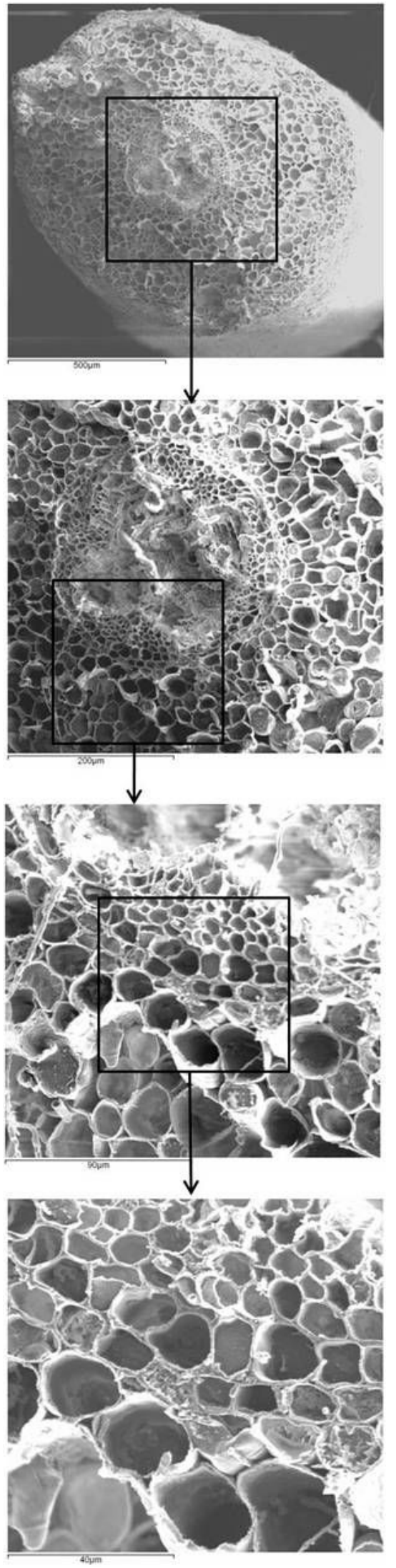

Fig. 7 - Details of ambient temperature scanning electron micrograph for 58-861 root cross-sections, proceeding from 500 to 40 $\mu \mathrm{m}$ of magnification. 
through the system, if uncoupled to a comprehensive ecophysiological analysis.

I-214 and Cretone were characterized by high $\mathrm{Cd}$ contents in the epidermis, which might suggest slow or reduced metal mobility towards the central cylinder. Whereas, 58-861, A4A and Poli had high Cd contents in the cortex. Cd was not detected in high percentage in internal tissues, central cylinder, being important for identifying any anatomical barrier to metal movement, as obstruction to the distribution of elements from the epidermis to the central cylinder. This, in general, could give control over mineral up take to the plant, but can also represent a tolerance strategy in phytoremediation systems. On the other hand, differential $\mathrm{Cd}$ localization in cross sections could suggest clone-specific metal mobility through internal root tissues. Other than exclusion strategy, internal detoxification is also an important strategy in metal tolerance, and these clones may have evolved different strategies for metal tolerance (e.g., Castiglione et al. 2009).

A partial root barrier may facilitate while a tight barrier may obstruct the uptake of water, ions and nutrients at the basal root zones (e.g., Soukup et al. 2007, Deng et al. 2004), therefore, these mechanisms could be likewise adopted by plants to control the metal and toxic elements distribution in roots. In this contest, the Casparian strip could be an obligatory passage to filter the aqueous absorbed solution, from the cortex to the central cylinder in roots (Haynes 1980), thus limiting $\mathrm{Cd}$ distribution crossways the root. In Fig. 7, sequential details show the significance of these anatomical structures in providing direction for studies on the control of metal diffusion in root tissues. Accordingly, the exclusion ability conferred by root barriers is presumably an important mechanism for $\mathrm{Cd}$ translocation to leaves, which might define clone-specific aptitude to preserve aboveground structures by toxic elements and to absorb metals for environmental cleaning. Micrographs did not show damages and necrosis induced by excess $\mathrm{Cd}$ in root tissues of any of the tested clones.

An interesting relationship was found between metal and $\mathrm{Ca}$ contents, suggesting that the accumulation of $\mathrm{Cd}$ did not interfere with macronutrient absorption, while these clones cope with metal stress. There is no specific transporter for selective Cd uptake, but the metal could also permeate through $\mathrm{Ca}$ channels, being both divalent cations (Hinkle et al. 1992, Perfus-Barbeoch et al. 2002). The distribution of $\mathrm{Ca}$ in roots was not affected by $\mathrm{Cd}$, except in Poli (root levels), in 58-861 (root cross-section), and in $\mathrm{I}-214$ that showed lower $\mathrm{Cd}$ contents in treated than control roots. Results on Ca distribution in roots might certificate efficient transport $\mathrm{Ca}$-channels under excess $\mathrm{Cd}$, and/or metal concentration below critical threshold. Commonly, high concentrations of heavy metals may block plant water channels and also affect ion channels and transport of osmotically active elements, which provide the driving force for water transport (Eckert et al. 1999).

Both high contents of $\mathrm{Cd}$ and $\mathrm{Fe}$ were found in root portions, such as in central and distal zones for 58-861, and in apex for Poli. Fodor et al. (2005) showed that Cd contents increased in root and shoot with Fe-chelates, while, in contrast, Cohen et al. (1998) observed that $\mathrm{Fe}$ deficiency induced the expression of transporter, which might facilitate the transport of heavy-metal divalent cations, such as $\mathrm{Cd}^{2+}$ and $\mathrm{Zn}^{2+}$, in addition to $\mathrm{Fe}^{2+}$. Possible mechanisms of enhanced Cd uptake could be explained by high affinity of nutrient transporter for metal uptake. For instance, Cohen et al. (1998) and Vert et al. (2002) observed the induction of a Fe transporter that could account for enhanced uptake of divalent cations, including $\mathrm{Cd}$ and $\mathrm{Fe}$ respectively, in $\mathrm{Fe}$-deficient plants.

In addition, $\mathrm{P}$ was not differently distributed in root cross-sections, but it was high when $\mathrm{Cd}$ content was low, such as in central zone for A4A and Poli. Williams \& David (1977) observed that Cd uptake was also affected by the distribution of phosphate in the root zone, because the addition of phosphate led to the proliferation of roots in the soil phosphate-treated layers. As a result, experiments in hydroponics do not represent the best environment to define the role of $\mathrm{P}$ in Cd uptake (Duncan \& Ohlrogge 1958).

Overall, Cd tolerance could be defined by metal distribution and by lack of interference with the distribution of macronutrients into root tissues. Again, dynamics of $\mathrm{Cd}$ distribution in roots could be also responsible for the clone-specific ability to cope with high $\mathrm{Cd}$ concentrations and for their overall high tolerance to Cd. Finally, the large root concentrations observed in this experiment, although probably partly due to high $\mathrm{Cd}$ availability in hydroponics, might indicate that metal removal by roots at the end of the remediation process would allow extraction of an additional amount of $\mathrm{Cd}$.

The accumulation and distribution of $\mathrm{Cd}$ in roots were important traits for the evaluation and screening of these clones under excess Cd. Clone 58-861 could maintain large and widely resistant root system absorbing high metal content, and thus has great potential applications in large-scale phytoremediation projects. As opposite, clone Poli might either have high metal translocation to leaves (see also Zacchini et al. 2009), or low potential to absorb high Cd contents. Clone SS5 was not affected by $\mathrm{Cd}$ excess at the level of root length, though showing metal content comparable to other clones.

We conclude that $\mathrm{Cd}$ accumulation in root levels cannot be unquestionably used as indicator of the ability of Salicaceae to translocate metal, while Cd localization in root cross-sections would suggest clone-specific control mechanisms to mineral uptake. However, information obtained by SEMEDXMA could contribute to programs aimed at elucidating functional and structural aspects of plant-metal interaction.

\section{Acknowledgements}

We acknowledge the Project "Molecular, physiological, and agronomic analyzes for selecting and managing Salicacee in phytoremediation" (MIUR, PRIN 2008) for financial support and IBAF-CNR for experimental maintenance.

\section{References}

Alcántara E, Romera FJ, Cañete M, de La Guardia MD (1994). Effects of heavy metals on both induction and function of root $\mathrm{Fe}$ (III) reductase in Fe-deficient cucumber (Cucumis sativus L.) plants. Journal of Experimental Botany 45: 1893-1898. - doi: 10.1093/jxb/45.12.1893

Arnon DI, Hoagland DR (1940). Crop production in artificial culture solutions and in soils with special reference to factors influencing yields and absorption of inorganic nutrient. Soil Science 50: 463-483.

Boot RGA, Mensink M (1990). Size and morphology of root systems of perennial grasses from contrasting habitats as affected by nitrogen supply. Plant and Soil 129: 291-299. - doi: 10.1007/ BF00032425

Boulila Zoghlami L, Djebali W, Chaïbi W, Ghorbel MH (2006). Modifications physiologiques et structurales induites par l'interaction cadmium-calcium chez la tomate (Lycopersicon esculentum). C.R. Biologies 329: 702-711. - doi: 10.1016/j.crvi.2006.05.003

Castiglione S, Todeschini V, Franchin C, Torrigiani P, Gastaldi D, Cicatelli A, Rinaudo C, Berta G, Biondi S, Lingua G (2009). Clonal differences in survival capacity, copper and zinc accumulation, and correlation with leaf polyamine levels in poplar: A large-scale field trial on heavily polluted soil. Environmental Pollution 157: 2108-2117. - doi: 10.1016/j.envpol.2009.02.011

Clemens S (2006). Toxic metal accumulation, responses to exposure and mechanisms of tolerance in plants. Biochimie 88: 1707-19. - doi: 10.1016/j.biochi.2006.07.003

Cocozza C, Minnocci A, Tognetti R, Iori V, Zacchini M, Scarascia Mugnozza G (2008). Distribution and concentration of cadmium in root tissue of Populus alba determined by scanning electron microscopy and energy-dispersive x-ray microanalysis. iForest 1: 96-103. - doi: 10.3832/ ifor0458-0010096

Cohen CK, Fox TC, Garvin DF, Kochian LV (1998). The role of iron-deficiency stress responses in stimulating heavy-metal transport in plants. Plant Physiology 116: 1063-1072. - doi: 10.1104/pp.116.3.1063

Connolly EL, Fett JP, Guerinot ML (2002). Ex- 
pression of the IRT1 metal transporter is controlled by metals at the levels of transcript and protein accumulation. Plant Cell 14:1347-57. doi: $10.1105 /$ tpc.001263

Deng H, Ye ZH, Wong MH (2004). Accumulation of lead, zinc, copper and cadmium by 12 wetland plant species thriving in metal-contaminated sites in China. Environmental Pollution 132: 2940. - doi: 10.1016/j.envpol.2004.03.030

Dickinson NM (2000). Strategies for sustainable woodland on contaminated soils. Chemosphere 41: 259-263. - doi: 10.1016/S0045-6535(99) 00419-1

Dos Santos Utmazian MN, Wieshammer G, Vega R, Wenzel WW (2007). Hydroponic screening for metal resistance and accumulation of cadmium and zinc in twenty clones of willows and poplars. Environ Pollution 148: 155-65. - doi 10.1016/j.envpol.2006.10.045

Duncan WG, Ohlrogge AJ (1958). Principles of nutrient uptake from fertilizer bands. II. Root development in the band. Agronomy Journal 50: 605-608.

Eckert M, Biela A, Siefritz F, Kaldenhoff R (1999). New aspects of plant aquaporin regulation and specificity. Journal of Experiment Botany 50: 1541-1545. - doi: 10.1093/jexbot $/ 50$ 339.1541

Fodor F, Gáspár L, Morales F, Gogorcena Y, Lucena JJ, Cseh E, Kröpf K, Abadía J, Sárvári É (2005). Effects of two iron sources on iron and cadmium allocation in poplar (Populus alba) plants exposed to cadmium. Tree Physiology 25: 1173-1180. - doi: 10.1093/treephys/25.9.1173

Frey B, Brunner I, Walther P, Scheidegger C, Zierold C (1997). Element localization in ultrathin cryosections of high-pressure frozen ectomycorrhizal spruce roots. Plant Cell and Environment 20: 929-937 - doi: 10.1046/j.1365-3040.1997. d01-132.x

Frey B, Keller C, Zierold K, Schulin R (2000). Distribution of $\mathrm{Zn}$ in functionally different leaf epidermal cells of the hyperaccumulator Thlaspi caerulescens. Plant, Cell and Environment 23 675-687. - doi: 10.1046/j.1365-3040.2000 00590.x

Haynes RJ (1980). Ion exchange properties of roots and ionic interactions within the root apoplasm: their role in ion accumulation by plants. Botanical Review 46: 75-99. - doi: 10.1007/ BF02860867

Hinkle PM, Shanshala ED, Nelson EJ (1992). Measurement of intracellular cadmium with fluorescent dyes. Further evidence for the role of calcium channels in cadmium uptake. Journal of Biological Chemistry 267: 25553-25557.

Kieffer P, Schröder P, Dommes J, Hoffmann L, Renaut J, Hausman JF (2009a). Proteomic and enzymatic response of poplar to cadmium stress. Journal of Proteomics 72: 379 - 396. - doi: 10.1016/j.jprot.2009.01.014

Kieffer P, Planchon S, Oufir M, Ziebel J, Dommes J, Hoffmann L, Hausman JF, Renaut J (2009b). Combining proteomics and metabolite analyses to unravel cadmium stress-response in poplar leaves. Journal of Proteome Research 9: 400-17. - doi: 10.1021/pr800561r

Lasat MM, Fuhrmann M, Ebbs SD, Cornish JE, Kochian LV (1998). Phytoremediation of a radiocesium contaminated soil: evaluation of cesium- 137 bioaccumulation in the shoots of three plant species. Journal of Environmental Quality 27: 165-168. - doi: 10.2134/jeq1998. $00472425002700010023 x$

Lasat MM, Norvell WA, Kochian LV (1997). Potential for phytoextraction of ${ }^{137} \mathrm{Cs}$ from a contaminated soil. Plant Soil 195: 99-106. - doi: 10.1023/A:1004210110855

Laureysens I, De Temmerman L, Hastir T, Van Gysel M, Ceulemans R (2005). Clonal variation in heavy metal accumulation and biomass production in a poplar coppice culture. II. Vertical distribution and phytoextraction potential. Environmental Pollution 133: 541-551. - doi: 10. 1016/j.envpol.2004.06.013

Lunácková L, A Sottníková A, Masarovicová E, Lux A, Streško V (2003). Comparison of cadmium effect on willow and poplar in response to different cultivation conditions. Biologia Plantarum 47: 403 - 411. - doi: 10.1023/ B:BIOP.0000023884.54709.09

Maser P, Thomine S, Schroeder JI, Ward JM,Hirschi K, SzeH, et al. (2001). Phylogenetic relationships within cation transporter families of Arabidopsis. Plant Physiology 126: 1646-1667. doi: 10.1104/pp.126.4.1646

Merkl N, Schultze-Kraft R, Infante C (2005). Phytoremediation in the tropics influence of heavy crude oil on root morphological characteristics of graminoids. Environmental Pollution 138: 86-91. - doi: 10.1016/j.envpol.2005.02.023 Merrington G, Alloway BJ (1994). The flux of Cd, $\mathrm{Cu}, \mathrm{Pb}$ and $\mathrm{Zn}$ in mining polluted soils. Water Air Soil and Pollution 73: 333- 344. - doi: 10.1007/BF00477997

Perfus-Barbeoch L, Leonhardt N, Vavasseur A, Forestier C (2002). Heavy metal toxicity: cadmium permeates through calcium channels and disturbs the plant water status. Plant Journal 32: 539-548. - doi: 10.1046/j.1365-313X.2002. 01442.x

Pietrini F, Zacchini M, Iori V, Pietrosanti L, Bianconi D, Massacci A (2010). Screening of poplar clones for cadmium phytoremediation using photosynthesis, biomass and cadmium content analyses. International Journal of Phytoreme- diation 12:105-120. - doi: 10.1080/ 15226510902767163

Pulford ID, Watson C (2003). Phytoremediation of heavy metal-contaminated land by trees - a review. Environment International 29: 529-540. doi: 10.1016/S0160-4120(02)00152-6

Robinson BH, Mills TM, Petit D, Fung LE, Green SR, Clothier BE (2000). Natural and induced cadmium-accumulation in poplar and willow: Implications for phytoremediation. Plant and Soil 227: 301-306. - doi: 10.1023/A: 1026515007319

Salt DE, Smith RD, Raskin I (1998). Phytoremediation. Annual Review Plant Physiology and Plant Molecular Biology 49: 643-68. - doi: 10.1146/annurev.arplant.49.1.643

Shen ZG, Zhao FJ, McGrath SP (1997). Uptake and transport of zinc in the hyperaccumulator Thlaspi caerulescens and the non hyperaccumulator Thlaspi ochroleucum. Plant Cell Environment 20: 898-906. - doi: 10.1046/j.1365-3040. 1997.d01-134.x

Soukup A, Armstrong W, Schreiber L, Franke R, Votrubova O (2007). Apoplastic barriers to radial oxygen loss and solute penetration: a chemical and functional comparison of the exodermis of two wetland species, Phragmites australis and Glyceria maxima. New Phytologist 173: 264-278. - doi: 10.1111/j.1469-8137. 2006.01907.x

Vert G, Grotz N, Dédaldéchamp F, Gaymard F, Guerinot ML, Briat JF, Curie C (2002). IRT1, an Arabidopsis transporter essential for iron uptake from the soil and for plant growth. The Plant Cell 14: 1223-1233. - doi: 10.1105/tpc.001388

Wei S, Zhou Q (2006). Phytoremediation of cadmium-contaminated soils by Rorippa globosa using two-phase planting. Environmental Science and Pollution Research 13: 151-155. - doi: 10.1065/espr2005.06.269

Williams CH, David DJ (1977). Some effects of the distribution of cadmium and phosphate in the root zone on the cadmium content of plants. Australian Journal of Soil Research 15: 59-68. doi: 10.1071/SR9770059

Zacchini M, Pietrini F, Scarascia Mugnozza G, Iori V, Pietrosanti L, Massacci A (2009). Metal tolerance, accumulation and translocation in poplar and willow clones treated with cadmium in hydroponics. Water Air Soil Pollution 197: 23-34. - doi: 10.1007/s11270-008-9788-7

Zhou QX (2003). Interaction between heavy metals and nitrogen fertilizers applied in soil-vegetable systems. Bulletin of Environmental Contamination and Toxicology 71: 388-344. - doi: $10.1007 / \mathrm{s} 00128-003-0169-\mathrm{z}$ 